\title{
8 IDENTIFICATION OF NECESSARY FACTORS FOR SUCCESSFUL IMPLEMENTATION OF ERP SYSTEMS
}

\author{
A. N. Parr \\ Monash University \\ Australia \\ G. Shanks \\ University of Melbourne \\ Australia \\ P. Darke \\ Monash University \\ Australia
}

\begin{abstract}
The identification of factors which are necessary for successful implementation of enterprise resource planning (ERP) systems is of great importance to many organizations. ERP systems have to be configured and implemented, often by a team of business analysts and consultants over a period of months or years. The process is lengthy and expensive, and may include extensive business process reengineering. Given that the investment in these systems, including both the package and associated implementation costs, is measured in millions of dollars, failure to meet deadlines and budgets may result in substantial company loss. However, the literature on the ERP implementation process, and the factors which either facilitate or impede its progress, is not extensive. This research reports the first
\end{abstract}


stage of a research program which seeks to understand successful implementation of ERP systems. The objective, of the first phase was to identify what factors are necessary for successful ERP implementation, where success is understood as adherence to time and budgetary constraints. To accomplish this objective the authors studied 42 implementation projects by interviewing 10 senior members of multiple ERP implementation teams. Based on these interviews, 10 candidate necessary factors for successful implementation of ERP systems are identified. Of these 10, three are of paramount importance. They are management support of the project team and of the implementation process, a project team which has the appropriate balance of business and technical skills, and commitment to the change by all stakeholders. The next phase of the research will involve in-depth case studies to explore the relationship between these factors and broader contextual and process issues.

Keywords: Enterprise resource planning, success factors, system implementation, ERP implementation.

\section{Introduction}

One of the major information technology (IT) developments in the 1980s and 1990s has been the move by larger companies toward comprehensive, fully integrated software systems. Enterprise resource planning (ERP) is the generic name (Appleton 1997; Bowman 1997; Hecht 1997; McKie 1997) of this new class of packaged application software. The all-encompassing packaged solutions aim for total integration of all business processes and functions. A holistic picture of the business is represented in the information system within a single architecture. An ERP system has two important features. It facilitates a causal connection between a graphical model of key business processes and the software implementation of those processes, and it ensures a level of integration, and hence data integrity and security, which is not easily achievable with multiple software platforms.

The companies that create and deliver fully integrated software include SAP AG, Oracle Corporation, System Software Associates, Peoplesoft Inc., QAD Inc., Computer Associates International (CA) and Baan Co. The market leader is SAP, which has 39\% of the world market (Piszczalski 1997). Software such as SAP's ${ }^{1} R / 2$ and R/3 has offered companies a capacity to integrate their business plans and processes with their IT. The vendors of fully integrated software offer a package that is capable of processing all commercial functions of any company, no matter how large, diverse or geographically disparate the company's components may be. Moreover, the software is not limited to specific industry sectors: it can be configured for retail industries, mining companies, banks, airlines etc.

${ }^{1}$ Systems, Applications and Products (SAP) was developed by SAP AG. 
A company's investment in ERP systems is measured in millions of dollars. A recent survey (Eckhouse 1998) of 200 IT executives in the United States found that 25\% expected to spend more than $\$ 10$ million on a complete implementation of their ERP system. In total, the cost of ERP investment in 1997 for 20,000 companies was $\$ 10$ billion, which was an increase of 40\% on ERP sales for 1996 (Martin 1998). The financial investment is both in the software package and in related services. These services include consulting, training and system integration (Caldwell 1998). In 1997, Gartner Group reported that "companies spent \$19 billion" on ERP services (Caldwell 1998). The investment can also be measured in time. Implementation of the systems varies from six months to several years (Bancroft 1996; Bancroft, Seip and Sprengel 1998) and requires considerable infrastructure and planning. The size of implementation project teams varies with the scope of the project. For example, 300 people worked on GTE's 11 month implementation in the United States.

There is evidence (Ambrosio 1997; Fine 1995; Gartner Group 1998; Horwitt 1998; Martin 1998; Piszczalski 1997; Tebbe 1997) that both time and budgetary allocations for ERP implementation are being exceeded. Given this, plus the level of commercial investment in ERP systems, and the magnitude of the implementation task, it is critical to determine those factors which are necessary for an efficient implementation.

This paper reports the first stage of a research program which seeks to understand successful implementation of ERP systems. This stage is concerned with the identification of candidate necessary factors for ERP implementation success. We first review the general literature on system implementation and then on ERP implementation. From this, a list of candidate factors for successful implementation of ERP systems is synthesized. The factors identified in the literature are then used as one of the foundations for interviews with 10 senior ERP implementation managers. The other foundation is personal construct psychology (PCP). Because of the paucity of the literature on ERP system implementation success factors, this technique, which facilitates a less constrained response, is used to elicit factors not identified in the literature. The interviewees have been involved in 42 implementations of these systems and they equate "success" with the meeting of budgetary and time constraints. The interviews focussed on the factors which the practitioners believe, based on their experience, are the critical factors in determining that an ERP system will be implemented on time and on budget. The results of those interviews are then analysed and discussed. The next phase of the research will involve in-depth case studies to explore the relationship between these factors and broader contextual and process issues.

\section{System Implementation Success}

There have been numerous empirical studies on implementation success in information systems in general. Success has been described in terms of factors. Lists of factors can be misleading in that they ignore the relationship between the factors and organisational and cultural contexts (Bussen and Myers 1996). They also present a static perspective of success and do not capture the processes by which they operate and their interrelationships (Nandhakumar 1996). However, factors can be usefully combined with approaches which focus on understanding broader contextual and process issues to explain how and why factors and outcomes are related (Bussen and Myers 1996; Newman and Robey 
1992). In the following section we review major studies on implementation success in order to infer candidate success factors for ERP implementation. First, we consider implementation of customized information systems, then implementation of packaged systems in general, and finally implementation of large, integrated packaged systems.

\subsection{Successful Implementation of Information Systems}

"Success factors" has been an influential conceptual construct for system evaluation in information systems and there is a large body of research (DeLone and McLean 1992; Rivard and Huff 1988; Swanson 1974) which uses this concept. As Delone and McLean note (p. 69 and Table 4, p. 72), user satisfaction is the most widely used single criterion of IS success, probably because it is relatively easy to measure. Ginzberg (1981) chose to view success as user satisfaction. This he measured in terms of actual use of the system and users avowed satisfaction with the system. Lucas $(1979,1981)$ also used user satisfaction as a measure of successful implementation. These studies were conducted in laboratory settings, or in response to survey questions. In the latter, some researchers (Bailey and Pearson 1983; Ives, Olson and Baroudi 1983; Raymond 1985; Swanson 1974) used multiple measures of user satisfaction.

Another alleged factor which leads to successful IS implementation is user participation in system design. In the 1960 s, researchers considered user participation to be the key to the achievement of system quality, use and acceptance. Although the belief in the centrality of user participation in system design was strong, Ives and Olsen (1984) reviewed the relevant studies and found that strong evidence for its benefits had not been demonstrated. Nonetheless, in 1993 an issue of Communications of the ACM was devoted to participatory systems design. Barki and Hartwick (1994) distinguished

\section{Table 1. Implementation Success Factors for Information Systems in General}

\begin{tabular}{|l|l|}
\hline Factor & Study \\
\hline Team skills/availability & Reich and Benbasat (1990) \\
Champion & Beath (1991), Kanter (1983), Rogers (1983) \\
User satisfaction & Bailey and Pearson (1983), Ginzberg (1981), Ives, \\
& Olson and Baroudi (1983), Lucas (1979, 1981), \\
& Raymond (1985), Swanson (1974) \\
User participation & Barki and Hartwick (1989), Keil and Erran (1995) \\
User acceptance & Benbasat and Dexter (1986), Davis, Bagozzi and \\
& Warshaw (1989), Ginzberg (1981), Robey (1979), \\
& Swanson (1987) \\
Usage & Baroudi, Olsen and Ives (1986), Lucas (1985) \\
Management support & Alter and Ginzberg (1978), Lawrence and Low \\
Resources & (1993), Steinbart and Nath (1992) \\
Reich and Benbasat (1990)
\end{tabular}


user participation from user involvement and user attitude, and developed separate measures of each. Their belief was that earlier problems may have been due to lack of an adequate measure of the user participation construct. Keil and Erran (1995) provided the notion of "customer-developer links" to measure effective user participation.

User acceptance is another alleged factor which contributes to successful systems implementation. Performance gains from new systems are lacking when users refuse the new system either by not using it or using it badly. There have been numerous studies which seek to explain the key determinants of user acceptance (Benbasat and Dexter 1986; Davis, Bagozzi and Warshaw 1989; Ginzberg 1981; Robey 1979; Swanson 1987).

There are other success factors, which do not focus on the users but rather on the organizational context. Reich and Benbasat (1990) note that adequate resources and appropriate team skills are pivotal features of successful implementation. Also, the presence of a champion for the system has been studied widely. Beath (1991) claimed that the literature suggests that the presence and influence of a champion may even be "the most important antecedent of a successful implementation of a mission-critical system" (p. 355).

Champions are not necessarily people with overt power which derives from funds, resources and authority. Beath refers to these latter people as sponsors. Champions are usually managers who, by their zeal and foresight, overcome obstacles to successful implementation (Beath 1991). The main reason why these people are considered to be central to successful implementation is that they have skills that are critical for handling organizational change. These skills include enthusiasm, optimism, vision and a talent for conflict management (Beath 1991; Kanter 1983; Rogers 1983).

Another major success factor is the level of management support (Alter and Ginzberg 1978; Lawrence and Low 1993; Steinbart and Nath 1992). This factor is important for several reasons such as leadership of change management, the encouragement of support for the new system and handling of resistance to change. One would expect that this factor would be crucial in the implementation of ERP systems given the degree of reengineering.

\subsection{Software Package Implementation}

There is also a substantial literature on the implementation of packaged software (Gross and Ginzberg 1984; Lucas, Walton and Ginzberg 1988; Lynch 1984). Lynch reviewed his work with financial packaged software implementation and connected that experience with a Lucas' (1981) theory of software implementation. Noting that until then "implementation" and its "success" had been understood in the context of customized system development, he contended that implementation with packaged software had special meaning. He argued that the key differences are that those who implemented packaged software had a very limited influence on the technical quality of the system; that the ability to involve users is constrained in this context; and that there is less time to work on a relationship with clients. Lucas, Walton and Ginzberg described a model of the implementation of packaged software. Four sets of variables were hypothesized to be crucial to the success of the implementation process. These were variables concerned with the organization, the needs of the adopter of the software, 
characteristics of the package itself, and discrepancies between the capacities of the software and the company processes.

Additionally, there is a body of literature on large, integrated package implementation, particularly manufacturing resource planning (MRP) system implementation. MRP systems, like ERP, integrate a base system with other modules such as forecasting, general ledger, order entry and accounts payable and receivable, and are large systems which represent a considerable investment. Again, like ERP, MRP systems were reported (White et al. 1982) to have implementation failure rates that were high. They differ from ERP in that they are oriented toward the manufacturing industry only. Nonetheless, the literature on implementation of these systems is a strong source for candidate factors for implementation success with ERP systems. In the literature on determinants of success in MRP, both organizational and manufacturing factors have been studied. This paper concentrates on the organizational factors since those that are peculiar to the manufacturing industry are not relevant to ERP systems which are intended to be inclusive of all industry sectors.

Contributions on the organizational/behavioral factors that influence MRP include Greiner (1967), Greiner and Barnes (1976), Leavitt (1965), and Woodward (1965). Duchessi et al. (1988) conducted a nationwide survey in the United States to identify the steps that lead to successful implementation of MRP systems. This survey built on the work of White et al. and Landvater (1985). Some of the factors they surveyed are irrelevant in an ERP context (for example, the presence of a prior inventory system). However of those that are relevant, management support, appropriate training, and rigorous project management were confirmed by their study to be necessary for successful MRP implementation. A further study by Duchessi, Schaninger and Hobbs (1989) sought to describe the "critical factors which underpin a successful implementation" (p. 77). They considered three categories of success factors: commitment from top management, factors related to the implementation process such as training and project planning, and hardware and software issues. The last category is not relevant here, since this study is not concerned with package selection. Again, they concluded that top management commitment, which is demonstrated by, for example, establishment and membership of a steering committee, is essential for successful implementation. They also concluded that inadequate training may be responsible for unsuccessful implementation. A study by Ang, Sum and Yang (1994) also found that lack of comprehensive training programs hinders the MRP implementation process.

With respect to project planning, Duchessi, Schaninger and Hobbs (1989) also concluded that "successful and less successful companies were equally likely to use a formal project planning and control system" (p. 84). Therefore, factors related to project planning were not held to be determinants of MRP implementation.

As can be seen above, a large range of factors have been held to be responsible for successful implementation, and some studies have generated conflicting results. Moreover, the factors vary depending on whether we are referring to implementation within the context of customised system development or package implementation, and between small-scale, dedicated packages and large, integrated systems. These factors may or may not be relevant to ERP implementation success. In particular, the emphasis on the users does not at face level have any relevance. The studies on user participation, involvement and attitude concerned organizations that were developing new information systems; ERP systems are packages and users are not involved in their development. 
ERP system implementation may be seen as more akin to project management than it is to system development. However, ERP systems are not simply installed. Over a period of months to years, users are heavily involved in the reengineering and configuration processes. Indeed, the project team is likely to be composed principally of users with business expertise (Bancroft 1996; Bancroft, Seip and Sprengel 1998), so their contribution is critical to successful implementation. On the other hand, some factors from this literature, such as management support and the presence of a champion, are plausible candidates, particularly in the context of substantial reengineering.

\subsection{ERP Implementation Success}

The literature that directly reflects on factors relevant for successful ERP implementation is not extensive. The systems are relatively new and a tradition of academic scrutiny and evaluation takes time to develop. What follows is a summary of this literature.

The studies by Bancroft (1996) and Bancroft, Seip and Sprengel (1998) provide nine "critical success factors" for ERP implementation. Many of these are consistent with the studies cited above. These include an emphasis on management support, the presence of a champion and an insistence on persistent communication with stakeholders. Factors that are important to successful project management, such as a good project methodology with clear milestones and appropriate training for the users and the project team, are also cited. However, some of the factors appear to be specific to ERP implementation. Businesses typically reengineer their businesses when they implement an ERP system. The level of reengineering implies that deep comprehension of business processes becomes a practical imperative for both process design and system configuration. The emphasis on reengineering leads to success factors such as the need to decide on substantial process changes prior to implementation; the need for a project manager whose skills range over technical, business and change management areas; and an understanding of the corporate culture which includes a deep analysis of the readiness and capacity for change. The nature of the implementation process also requires a project team composition contrary to that which might be expected in a normal large system implementation. Traditionally, the project team for such implementations is dominated by technical staff. With an ERP, the business analysts constitute $70 \%$ of the team and so it is important to choose a balanced team sufficiently flexible to adopt non-traditional roles. Finally, the length and complexity of the task require that teams should "expect problems to arise" and "commit to the change." This list of factors, which Bancroft provides, is derived from discussions with 20 practitioners and from studies of three multi-national corporation implementation projects. As such, it appears to be the most comprehensive and well evidenced of the guidelines which directly relate to ERP implementation, although the interview method is not described in detail. Bancroft, Seip and Sprengel noted that many of the factors are "classics" and not specific to ERP implementation. Nonetheless, they claim that each "takes on a greater significance" (p. 67) given the complexity of these projects.

Other researchers have views on successful implementation of ERP systems. Curran and Keller (1998, Chapter 3) argue that use of in-built templates, what they call the "blueprint" approach to reengineering is the key to fast implementation. Levin, Mateyaschuk and Stein (1998) contend that the empowerment of the project team and minimal customization are the keys to successful implementation. Martin $(1998$, p. 149) 


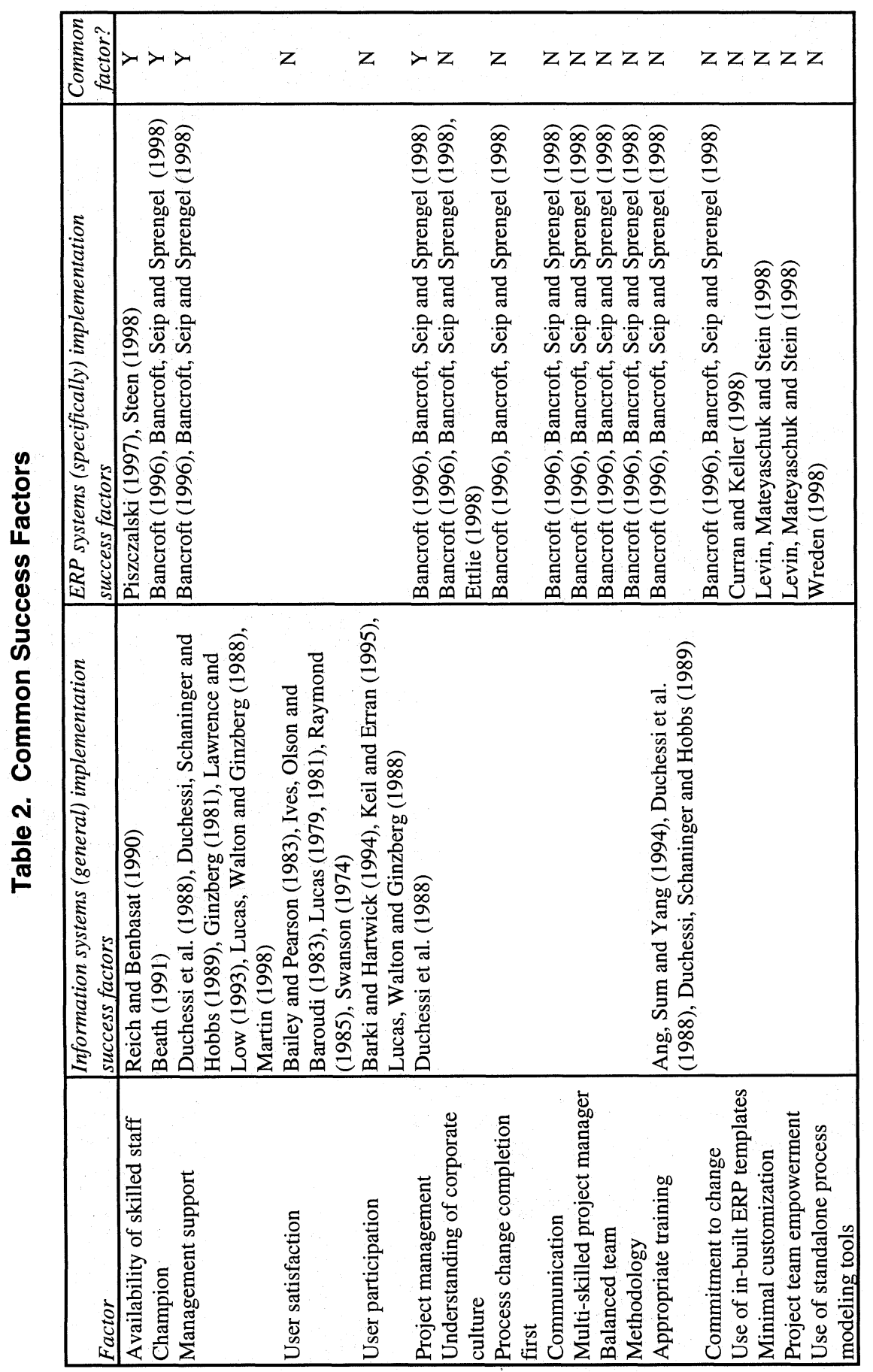


maintains that the most important success factor is "commitment to the process from the top levels of management." Langnau (1998) believes that the problem with implementation is under-estimation of budgets and time expenditures, so by implication the success factor is realistic budgetary and time targets and full testing. The pressure to implement quickly can, he suggests, result in inadequate testing. Ettlie (1998) suggests the key to success is "organizational culture change." His view is that the ability to manage major change is the key to successful implementation.

In the popular literature (Information Week, Computerworld, etc.), there are numerous "recipes" for success. Some (Caldwell 1998) see do-it-yourself (don't use ERP experts) as the key. Stedman (1998a) claims that a number of factors are impeding successful implementation. These include the level of reengineering required, a shortage of consulting professionals, lack of involvement by business users, the newness of the products, and the variation in set-up needs from site to site. Stedman (1998b) also suggests that unfriendly user interfaces and unforeseen costs in user training may be responsible for slow implementation. Steen (1998) suggests that a lack of experience among the IT professionals is a hindrance to successful implementation. Wreden (1998) contends that the use of process modeling tools is a factor in successful implementation. This contrasts with Curran and Keller, who claim the use of the ERP in-built tools is a preferred method.

\subsection{Synthesis of Candidate Success Factors}

If one synthesizes the literature from implementation of large systems in general and from implementation of ERP systems in particular, the list of success factors is long. Some alleged success factors are shown to be common to both (see Table 2); some are specific to information systems in general; and some are specific to ERP implementation.

In summary, the literature both on systems generally and ERP systems in particular revealed that the availability of skilled staff, the presence of a champion, appropriate training, rigorous project management and senior management support were all considered to be necessary. Many other factors (see Table 2) were identified but were not jointly cited. Because of the under-development of the research, all factors identified in both literatures became the basis for structured interviews. Further, the paucity of current research required the structured interviews to seek both validate factors identified to date and to elicit other potential factors.

\section{The Study}

Structured interviews were conducted with 10 implementation project managers, who between them had participated in 42 ERP implementation projects. Senior members of ERP project teams were interviewed in order to understand ERP systems implementation in practice and to elicit experienced practitioners' beliefs about factors which lead to successful implementation. The interviews were structured around the factors elicited from the literature review, but also provided scope for the interviewees to propose their own factors. 
The method used to validate factors inferred from the literature was a structured questionnaire delivered in an interview format. The method used to elicit factors other than those derived from the literature was personal construct psychology (PCP). PCP was created by George Kelly in 1955 and later refined by Kelly and others (AdamsWebber 1979, Boose and Bradshaw 1987). This tool has been used extensively in knowledge acquisition research to model the cognitive processes of human experts, and so was thought to be appropriate for the elicitation of the concepts of success/failure from those who are expert in ERP implementation. PCP is a theory concerning individual and group psychological processes, which suggests that experts function as anticipatory systems, by which it is meant that they develop conceptual models so as to better understand and make predictions concerning their immediate world. At the center of the conceptual models are sets of dichotomous constructs, such as "soft/hard," "male/female," and "success/failure." PCP is well accepted in psychology, management and education, and is an underlying mechanism for knowledge acquisition techniques in much expert systems development (Gaines and Shaw 1988).

\subsection{The Interviewees}

The participants had been involved in a total of 42 ERP implementation projects in Australia and the United States. They consisted of project managers from within implementation companies and project managers and senior consultants from ERP consultancy companies. One participant had ERP implementation experience both in Australia and in the United States. On average, participants had been involved in 4.5 ERP implementations. The ERP systems included SAP R/2, SAP R/3, Peoplesoft 7, Peoplesoft 7.5, and Oracle.

The range of industries represented in the implementations by these participants was large and diverse. It should be noted that several of the very large companies had had several implementation projects, as they chose either a series of "little bang" or "phased" implementations. All companies were large and many were multi-nationals. So the expertise of the interviewees' represents "state of the art" knowledge of ERP systems implementation in a broad range of international companies and industry sectors.

A summary of the participants and their experience is provided in Table 3.

\subsection{The Interviews}

The interviews were conducted in person and a structured interview method was used. However, after the formal interview, a less formal interview to follow up on points of interest was frequently conducted. Prior to each interview, the interviewer collected data on the company and, on average, the formal part of the interview lasted one hour. At commencement of the interview, it was explained that the research focused on factors that facilitated the meeting of budgetary and time constraints. Many interviewees provided data such as presentations on ERP implementation given to their staff, postimplementation evaluation written reports, and documentation relating to project team membership, responsibilities and milestones. The interview questionnaire, notes, individual communications, and documentation served as the study database. 
Table 3. Interviewees and their ERP Experience ${ }^{2}$

\begin{tabular}{|c|c|c|c|c|c|}
\hline Current & Current Company & & $\begin{array}{c}\text { No. } \\
E R P\end{array}$ & & \\
\hline $\begin{array}{c}\text { Position } \\
\text { Proin }\end{array}$ & Type & & Projects & Country & Industry Sector \\
\hline Project Manager & ERP Consultancy & $\begin{array}{l}\mathrm{SAP} \\
\mathrm{R} / 2 \\
\mathrm{R} / 3\end{array}$ & & Australia & $\begin{array}{l}\text { Oil } \\
\text { Chemicals } \\
\text { Construction } \\
\text { Automotive } \\
\text { Medical } \\
\text { Financial Services }\end{array}$ \\
\hline Project Leader & $\begin{array}{l}\text { Implementation } \\
\text { company }\end{array}$ & $\begin{array}{l}\mathrm{SAP} \\
\mathrm{R} / 3\end{array}$ & 3 & Australia & Chemicals \\
\hline $\begin{array}{l}\text { Project Manager/ } \\
\text { Acct. Systems } \\
\text { Manager }\end{array}$ & $\begin{array}{l}\text { Implementation } \\
\text { company }\end{array}$ & $\begin{array}{l}\text { SAP } \\
\mathrm{R} / 3\end{array}$ & 5 & Australia & Retail \\
\hline $\begin{array}{l}\text { Senior People- } \\
\text { soft Consultant }\end{array}$ & ERP Consultancy & PS 7/7.5 & 4 & $\begin{array}{l}\text { Australia } \\
\text { U.S.A. }\end{array}$ & $\begin{array}{l}\text { IT } \\
\text { Airline } \\
\text { Medical }\end{array}$ \\
\hline $\begin{array}{l}\text { Principal People- } \\
\text { soft Consultant }\end{array}$ & ERP Consultancy & $\begin{array}{l}\text { PS } 7 / 7.5 \\
\text { Oracle }\end{array}$ & 7 & $\begin{array}{l}\text { Australia } \\
\text { U.S.A }\end{array}$ & $\begin{array}{l}\text { Oil } \\
\text { IT } \\
\text { Airline }\end{array}$ \\
\hline $\begin{array}{l}\text { Manager of H.R. } \\
\text { and Payroll }\end{array}$ & $\begin{array}{l}\text { Implementation } \\
\text { company }\end{array}$ & $\begin{array}{l}\text { PS 7/7.5 } \\
\text { Oracle }\end{array}$ & 7 & $\begin{array}{l}\text { Australia } \\
\text { U.S.A }\end{array}$ & $\begin{array}{l}\text { Public Sector } \\
\text { Airline }\end{array}$ \\
\hline $\begin{array}{l}\text { Consultant/ } \\
\text { Functional Lead- } \\
\text { er Payroll }\end{array}$ & ERP Consultancy & PS 7/7.5 & 2 & $\begin{array}{l}\text { Australia } \\
\text { U.S.A }\end{array}$ & $\begin{array}{l}\text { IT } \\
\text { Airline }\end{array}$ \\
\hline Product Manager & ERP Consultancy & $\begin{array}{l}\mathrm{SAP} \\
\mathrm{R} / 3\end{array}$ & 4 & Australia & $\begin{array}{l}\text { Manufacturing } \\
\text { IT } \\
\text { Communications }\end{array}$ \\
\hline $\begin{array}{l}\text { National Man- } \\
\text { ager - Systems } \\
\text { Dev. IT }\end{array}$ & $\begin{array}{l}\text { Implementation } \\
\text { company }\end{array}$ & $\begin{array}{l}\mathrm{SAP} \\
\mathrm{R} / 3\end{array}$ & 1 & Australia & Automotive \\
\hline $\begin{array}{l}\text { Technical Dev. } \\
\text { Manager } \\
\text { Total }\end{array}$ & $\begin{array}{l}\text { Implementation } \\
\text { company } \\
\mathbf{1 0} \\
\end{array}$ & $\begin{array}{l}\text { SAP } \\
\mathrm{R} / 3\end{array}$ & 42 & Australia & Medical \\
\hline
\end{tabular}

The structured interviews had several objectives. In Section A, the aim was to determine the experience of the interviewee. Depending on that experience, up to six implementations were then documented (Section B). The documentation included details of the ERP elements and the length and cost of implementation. Three different methods were then used to elicit success factors for ERP implementation. The first method (Section C) used PCP and the previously documented projects. Here the aim was to

${ }^{2}$ Note that up to six implementations per person were documented. Interviewees may have had more experience than this. 
elicit, without prompting, the interviewee's beliefs about the factors which contributed to the success or failure of those projects. Three of the projects were selected at random, and then the interviewee was asked:

In what important ways are two of these projects the same, but different from the third, in terms of factors which you believe have contributed to the success or failure of the project?

This procedure was repeated until no further success/failure attributes were forthcoming.

In Section D, the interviewees' responses were restricted to factors derived from the literature. This combination of factors was tested first by elicitation of a ranking on a Likert scale, then by elicitation of a Boolean scale. The ranking on the Likert scale ranged from 1 (the factor is unimportant) to 5 (the factor is essential). The Boolean response (the factor is/is not necessary for successful implementation) aimed to overcome the tendency to name all factors elicited with the Likert scale as equally important, and thus to distinguish important from necessary factors.

So the question asked was:

If a factor is so important that, without it, an implementation could not meet time and budgetary constraints, please tick. (Otherwise leave blank.)

The data gathered from "open" PCP elicitation and from the constrained responses to the literature factors was then analyzed to identify and delineate candidate necessary success factors for ERP implementation.

\section{Analysis and Discussion of Results}

This discussion is divided into the factors elicited from the less constrained sections of the interviews in which PCP elicitation was used and the factors gleaned from the response to those factors which emerged in the literature.

\subsection{PCP Elicitation of Success Factors (Section C)}

In this section, interviewees were directly reflecting on their experience of ERP implementation cases, and from these inferring factors which either facilitated or hindered successful implementation. As such, this section drew a more elaborate response from those with the most experience. All the factors were expressed either as "success factors" or as factors which had in their experience led to failure given that the factor was absent. So the presence of the factor is positive and its absence is seen as an inhibitor of successful implementation. Many factors were elicited, but factors which were unique or received little support are not reported here. Only one factor was elicited from all interviewees. Senior management support was held to be indispensable for successful implementation. Seven other factors were elicited from nine of the 10 interviewees. These eight factors are discussed below.

1. Management support. Management support was the one factor elicited from all interviewees. On the basis of those implementations which were successful in meeting budgetary and time constraints, all stated categorically that senior 
management support was indispensable to the achievement of that success. Many stressed that such support was best when it was accompanied by close monitoring of and interaction with the project. This was demonstrated in several ways. On successful projects, management established a steering committee and one or more project teams. A member of senior management with responsibility for the implementation sat on the steering committee, and the project director had access to that person. Senior management delineated the functions of both the steering committee and the project Team(s), and established regular reporting mechanisms. Apart from these operational functions, senior management support was crucial to overcome the inevitable setbacks and conflicts that arise during such a large undertaking. A number of factors, including the level of business process reengineering, the depth and breadth of company change, conflict between consultants and in-house members of the project team, and the steep learning curve for project team members contributed to an atmosphere that was often stressful. The role of management in finding a way through the problems and tension was critical.

2. The best people full-time on the project team. Project teams typically consist of business analysts, users and technical experts from within the implementation company and consultants from external companies. Consultants regularly complained that the people released by the company were only intermittently available, and/or were not the most experienced and best available. In the words of one interviewee, the project team should have "the best people full time." The members of the company who are released to provide the business expertise, which forms the foundation for the new system configuration, should be the best available and should be released from all other duties to work on the implementation. This was not always achieved for several reasons. The "best" people are usually doing a core task elsewhere in the company, and releasing them raises problems of backfilling and its associated costs. Also, the people required need an overview of company processes, access to senior management, and to be multi-talented communicators with skills in technical, business, and people management. These people are critical to the whole implementation, and are involved in the design of the system, its testing and the training of the users. A related problem for the company is that such people are in high demand and the experience gained in the implementation may result in their movement out of the company. Several interviewees suggested that adequate remuneration was required to guard against this.

There was one exception to the view articulated above. One very experienced interviewee had developed a unique approach to team composition, which he referred to as a "virtual project team." These were employees who were scattered throughout the organization, were in constant electronic contact, and were dedicated on a part-time basis only to the project. All of these employees were selected on the basis of substantial company experience and individual talent. This method was not replicated elsewhere, although the interviewee had used it several times and believed it to be highly effective. It is worthy of further investigation.

3. Empowered decision makers on project team and effective decision-making. There were varying configurations of project teams: some divided the technical from the business experts; in some, the consultants were available only part-time; others placed all team members together in a "war-room" environment. However, most interviewees stressed that whatever the mechanics of the team, one factor was 
crucial: the members of the project team(s) must be empowered to make quick decisions. Many reflected that delays in implementation had been due to slow decision making, because the decision had to be moved up the line, and/or wait upon senior management meetings. A related factor was the establishment of streamlined, publicly known decision-making processes. Determining and publishing the decision-making processes is an initial function of the steering committee.

4. Deliverable dates. Interviewees stressed that implementation was more likely to fail when the dates for deliverables were fluid and/or not communicated well in advance. There is one date that shapes all ERP implementation: the year 2000. Many of these systems are being implemented in order to achieve Y2K compliance for the company.

5. Presence of a champion. Although they did not distinguish champions from sponsors, interviewees agreed that the presence of a champion had facilitated many successful projects. If the person was a senior member of management so much the better, but often the person was the project manager. The role of advocate of the benefits of the system was crucial, particularly during the difficult times referred to above. This person was the one who was unswerving in promoting the benefits of the new system, even when users lauded (as they frequently did) the advantages of the old system.

6. "Vanilla ERP": minimal customization and uncomplicated option selection. One factor that related directly to the software was stressed. This was the need to choose minimal customization of the ERP. Where possible, the business should adopt the processes and options built into the ERP, rather than seek to modify the ERP to fit the business. The problem appeared to be that the belief that a business is unique is common, and leads to time consuming and lengthy customization. A related factor was selection of complicated ERP options during configuration when a simpler alternative was available. The practitioners know this approach of minimal customization and uncomplicated option selection as "Vanilla ERP." Two of the most experienced project managers claimed that this factor was in fact more important in achieving time and budget limits than any other factor.

7. Smaller scope and functionality. Not surprisingly, projects with smaller scope and functionality were likely to be more successful than more complex ones. The longest documented implementation took four years and was the most complex. It was a SAP R/2 implementation and all but one of the 12 main modules, and all associated submodules, were implemented. The shortest implementation documented took six months, but only two modules were implemented and the user group was relatively small.

8. Definition of scope and goals, roles and responsibilities. Successful system implementation means that the steering committee determines the scope of the project in advance and then adheres to it. One company changed the scope and resources four months into the implementation. Originally, they had intended to implement a SAP system in Australia then roll out the system across a range of Asian countries. Then came the South East Asian crisis and, four months into the implementation, the plan changed from a multi-national to a national implementation. This resulted in a change of consultancy company and a range of changes that affected both the timeline and the budget. This company expected the initial implementation to take 15 months and the final time was 27 months. 
Table 4. Success Factors Elicited by PCP

\begin{tabular}{|c|c|c|c|}
\hline Management & Personnel & Software & Project \\
\hline $\begin{array}{l}\text { Management } \\
\text { support } \\
\text { Deliverable dates } \\
\text { communicated } \\
\text { well in advance } \\
\text { Empowered } \\
\text { decision makers }\end{array}$ & $\begin{array}{l}\text { "Best people } \\
\text { full time" } \\
\text { A champion }\end{array}$ & "Vanilla ERP" & $\begin{array}{l}\text { Smaller scope and func- } \\
\text { tionality } \\
\text { Definition of scope and } \\
\text { goals, roles and responsi- } \\
\text { bilities }\end{array}$ \\
\hline
\end{tabular}

The above eight factors may be categorized as relevant to personnel, management, project management, or software. In terms of personnel, it was stressed that highly skilled business resources should be available full time on the project; that the presence of a champion facilitated success; and that there should be senior empowered personnel on the project team, so that rapid decision making was facilitated. In terms of software, there was substantial agreement that success arose from making as few changes as possible to the software and from selection of the most straightforward configuration options. In terms of the project itself, projects with smaller scope and functionality were likely to be more successful than more complex ones and some of the elements of all successful project management-for example, deliverable dates, good project planning, clear definition of goals, roles and responsibilities-were emphasized. Additionally, the importance of quick decision making and streamlined decision-making processes was emphasized. A summary of the findings of this part of the interview is provided in Table 4.

\subsection{Response to Success Factors Reported in the Literature (Section D)}

As previously stated, the factors which emerged from the literature were assessed first using a Likert scale and then a Boolean scale. The Likert scale ranked factors from 1 (unimportant) to 5 (essential). The only factor from the literature that was ranked, on average, by all participants as being very important to essential (4.5) was a balanced team. Five other factors were scored by the participants as very important. These were commitment to the change, communication, advocacy, corporate readiness and a multiskilled project manager. Perhaps surprising, almost no one thought it was important to complete major process changes first. Also, it was considered by all except one participant that selection of a methodology was not particularly important. The list of average responses is shown in Table 5.

Some caution has to be exercised with these results. When all 10 interviewees' responses are tabulated, all factors in this section scored in the range "important" to "essential." However, when taken together with the Boolean (necessary/not necessary) responses, a sharper picture emerges. When encouraged to discriminate between those factors without which time and budgetary constraints could not be met, and those which, while important, may not be necessary, fewer factors were selected. However, 
Table 5. Important Factors for ERP Success

$$
\text { ( } 1 \text { = unimportant, } 5 \text { = essential) }
$$

\begin{tabular}{lc}
\hline Factor & Average \\
\hline Balanced team & 4.5 \\
Commitment to change & 4.3 \\
Communication & 4.2 \\
Advocacy & 4.2 \\
Corporate culture readiness & 4.0 \\
Multi-skilled project manager & 4.0 \\
User training & 3.6 \\
Methodology & 3.5 \\
Project team training & 3.4 \\
Complete business processes & 3.1 \\
\hline
\end{tabular}

Table 6. Necessary Success Factors

\begin{tabular}{lcc}
\hline Necessary Factor? & Necessary & Not Necessary \\
\hline Balanced team & 8 & 2 \\
Commitment to change & 7 & 3 \\
Communication & 5 & 5 \\
Project team training & 4 & 6 \\
Corporate culture readiness & 3 & 7 \\
Advocacy & 3 & 7 \\
Project manager & 2 & 8 \\
Methodology & 2 & 8 \\
User training & 2 & 8 \\
Completion of business processes & 1 & 9 \\
\hline
\end{tabular}

Table 7. Combined Success Factors

\begin{tabular}{llll}
\hline & Factors elicited by PCP & Factors based on Response to Literature \\
\hline 1 & Management support & 1 & Balanced team \\
2 & Best people full-time & 2 & Commitment to change \\
3 & Empowered decision makers & \\
4 & Deliverable dates & \\
5 & Champion & \\
6 & Vanilla ERP & \\
7 & Smaller scope & \\
8 & Definition of scope and goals & \\
\hline
\end{tabular}

the ranking of the principal factors remained the same. Again, a balanced team was selected by eight of the 10 participants as being necessary, and seven said commitment to the change was necessary. These two factors were top scorers in the previous section. 
All other factors were deemed necessary by half or fewer of the participants. The least necessary were completion of business processes (one interviewee), a multi-skilled project manager (two interviewees), a good methodology (two interviewees) and user training (two interviewees). The number of interviewees who selected a factor as necessary/not necessary is shown in Table 6.

If one combines the responses to the Likert and the Boolean scales, the literature factors which were validated are a balanced team and commitment to the change.

\subsection{Synthesis of PCP and Literature Factors (Sections $C$ and D)}

If one combines the findings from the two sections, 10factors (see Table 7) emerge as candidate factors for successful ERP implementation.

Three of these factors are of paramount importance: these are management support, a balanced team, and commitment to the change. Management support is of paramount importance because it was the only factor elicited from all interviewees in the PCP section. A balanced team and commitment to the change were the only necessary factors to emerge from the literature response section. Additionally, the seven factors which were supported by nine of the 10 interviewees in the PCP section are shown in Table 7.

\section{Conclusions and Further Research}

This research has been concerned with the identification of ERP implementation success factors. Since it is a relatively new area, the approach has been to draw upon prior relevant research and then to synthesize that with the directly applicable research on ERP implementation success factors. Senior ERP practitioners were then interviewed using the results of the synthesized literature to guide the interviews. Of the 18 candidate factors from the literature (see Table 2, Common Success Factors), only six were confirmed by the interviews. These were management support, a champion, a balanced team, commitment to the change, minimal customization, and project team empowerment. The interviewees rejected 12 factors from the literature as being necessary for ERP implementation. Additionally, the interviewees proffered four factors that were not found in the literature. These are the best people full-time, smaller scope, deliverable dates, and the definition and adherence to scope and goals.

An analysis of the interviews demonstrates that there is a combination of success factors peculiar to ERP implementation. The three overriding factors are management support, a balanced team, and commitment to the change. A range of further factors (Table 7) has been identified as at least desirable. The prime implication of this research for practitioners is that the three overriding factors-management support, a balanced team, and commitment to the change-are necessary for successful implementation. Proceeding with an implementation when one or more of the factors is absent will lead to budget and time over-runs. The other seven factors are at least desirable, and so their absence should be grounds for concern.

Further research is necessary to refine the factors and to conduct in-depth case studies to explore the relationship between these factors and broader contextual and process issues. First, the three major factors in ERP implementation are in need of clarification. The interviewees have suggested elements of each. For example, it appears 
that establishment of a rapid decision making process is an element of management support. Similarly "management support" in this context appears to involve at least the establishment of a steering committee, close monitoring of the project team and the establishment of a clear public process for rapid decision making. Also, the emphasis on the best people to be released full-time to the project team raises a number of questions. How are the "best people" identified? What process ensures they are selected? The elements of each of these concepts are in need of further clarification. Apart from the three principal factors, the elements shown in Table 7 are clearly important, and it remains unclear whether they are necessary and/or desirable. Second, case studies can be used to explain the interrelationships between these factors, their interactions with organizational and cultural contexts, and the dynamics of the processes of ERP implementation.

The PCP methodology was found to be particularly useful in the elicitation of factors where existing literature is sparse. In this study, four of the 10 factors emerged from the PCP section of the interviews, rather than the existing literature. This technique, which draws directly upon the case experience of interviewees, provided wide-ranging and thoughtful data.

Another finding of this research is that much of the existing literature on system implementation does not have any direct bearing on ERP implementation. As stated, six of 17 candidate factors were validated by this research. Elements of traditional project management, an approach to the software, management support, and the personnel who are released to the project team combine to determine a successful implementation. The only factor from the existing general literature that is unequivocally validated by this research is management support. The literature on ERP system implementation success, scarce though it may be, is more accurate. Particularly, Bancroft's "nine factors" were all viewed as - at least-important. (However, when asked to identify factors that are necessary, only a balanced team and commitment to the change were viewed as necessary.)

The research in the existing general literature on the user's role (participation/usage/involvement, etc.) is not directly validated. However a "balanced team" is considered necessary, and it may be that a redefinition of the user's role would be worthy of further research. The elements of "a balanced team" were, to some extent, elucidated. A balanced team involved the right composition for the project team; a balance between users, business analysts, consultants and technicians. In the implementations documented, there was considerable variation in the team composition. The role of the users on the implementation team is an interesting new one, since they are not passive system users, but rather equals with the technical staff in that they contribute their business expertise. Case study research on these user experts, and on what constitutes, in this context, a balanced team, management support and commitment to the change, is required to provide a deep understanding of each of the factors and to strengthen and substantiate the findings of this study.

\section{References}

Adams-Webber, J. R. Personal Construct Theory: Concepts and Applications. Chichester, United Kingdom: Wiley, 1979.

Alter, S., and Ginzberg, M. "Managing Uncertainty in MIS Implementation," Sloan Management Review (20:1), 1978, pp. 23-31. 
Ambrosio J. "Experienced SAP Users Share Ideas with Newbies," Online News Story August 27, 1997.

Ang, J.; Sum, C.; and Yang, K. "MRP 11 Company Profile and Implementation Problems: A Singapore Experience, " International Journal of Production Economics (34), 1994, pp. 3545.

Appleton, E. L. "How to Survive ERP," Datamation (43:3), March 1997, pp. 50-53

Bailey, J., and Pearson, S. "Development of a Tool for Measuring and Analyzing Computer User Satisfaction," Management Science (29:5), 1983, pp. 530-545.

Bancroft, N. Implementing SAP R/3. Greenwich, CT: Manning Publications, 1996.

Bancroft, N.; Seip, H.; and Sprengel, A. Implementing SAP $R / 3,2^{\text {nd }}$ ed., Greenwich, CT: Manning Publications, 1998.

Barki, H., and Hartwick, J. "Rethinking the Concept of User Involvement, MIS Quarterly (13:1), 1989, pp. 53-63.

Barki, H., and Hartwick, J. "Measuring User Participation, User Involvement, and User Attitude," MIS Quarterly, March 1994, pp. 59-79.

Baroudi, J.; Olson, M.; and Ives, B. "An Empirical Study of the Impact of User Involvement on System Usage and Information Satisfaction," Communications of the ACM (29:3), 1986, pp. 232-238.

Beath, C. "Supporting the Information Technology Champion,” MIS Quarterly September 1991, pp. 355-371.

Benbasat, I., and Dexter, A. S. "An Investigation of the Effectiveness of Color and Graphical Presentation Under Varying Time Constraints," MIS Quarterly (10:1), March 1986, pp. 5984.

Boose, J. H., and Bradshaw, J. M. "Expertise Transfer and Complex Problems: Using AQUINAS as a Knowledge Acquisition Workbench for Knowledge-based Systems," International Journal of Man-Machine Studies (26), 1987, pp. 3-28.

Bowman, I. “ERP 'Coned Off' Expect Delays,” Manufacturing-Computer-Solutions (3:1), 1997, pp. 32-3.

Bussen, W., and Myers, M. "Executive Information Systems Failure: A New Zealand Case Study," Journal of Information Technology (12:2), 1996, pp. 145-153.

Caldwell, B. "GTE Goes Solo on SAP R/3," Information Week, June 8, 1998, p. 150

Curran, T., and Keller, G. SAP R/3 Business Blueprint: Understanding the Business Process Reference Model. Englewood Cliffs, NJ: Prentice Hall, 1998.

Davis, F. D.; Bagozzi, R. P.; and Warshaw, P. R. "User Acceptance of Computer Technology: A Comparison of Two Theoretical Models," Management Science, August 1989, pp. 982-1003.

DeLone, W. H., and McLean, E. R. "The Quest for the Dependent Variable," Information Systems Research (3:1), 1992, pp. 60-95.

Duchessi, P., Schaninger, C.; Hobbs, D.; and Pentak, L. "Determinants of Success in Implementing material Requirements Planning (MRP)," Journal of Manufacturing and Operations Management (1:3), 1998, pp. 263-304.

Duchessi, P.; Schaninger, C.; and Hobbs, D. "Implementing a Manufacturing Planning and Control Information System," California Management Review, Spring 1989, pp. 75-90.

Eckhouse, J. "Money Pours Into ERP,” Information Week, June 15, 1998, p. 220.

Ettlie, J. "R-and-D and Global Manufacturing Performance," Management Science (44:1), 1998, pp. $1-11$.

Fine, D. "Managing the Cost of Client-server," InfoWorld (17:11), 1995, p. 62.

Gaines, B., and Shaw, M. "Knowledge Acquisition Tools Based on Personal Construct Psychology,” http://ksi.cpsc.ucalgary.ca/articles/KBS/KER/KER1.html\#, 1988.

Gartner Group. "Implementing SAP R/3: Avoiding Becoming a Statistic," http://www.gartner. $\mathrm{com} /, 1998$.

Ginzberg, M. J. “Early Diagnosis of MIS Implementation Failure: Promising Results and Unanswered Questions," Management Science (27:4), April 1981, pp. 459-478. 
Greiner, L. M. "Patterns of Organizational Change," Harvard Business Review (45), 1967, pp. $119-130$

Greiner, L. M., and Barnes, L. B. "Organizational Change and Development in Organizational Behavior and Administration," in P. R. Lawrence, L. Barnes, and J. Lorsch (eds.), Homewood, IL: Richard D. Irwin, 1976, pp. 625-636.

Gross, P., and Ginzberg, M. "Barriers to the Adoption of Application Software Packages," Systems, Objectives, Solutions (4), 1984, pp. 227-234.

Hecht, B. "Choose the Right ERP Software," Datamation (43:3), March 1997, pp. 50-53.

Horwitt, E. "Enduring a Global Rollout—and Living to Tell About It," Computerworld (32:14), April 6, 1998, pp. 8-12.

Ives, B., and Olson, M. H. "User Involvement and MIS Success: A Review of the Research," Management Science, (30:5), May 1984, pp. 586-603.

Ives, B.; Olson, M. H.; and Baroudi, J. J. "The Measurement of User Information Satisfaction," Communications of the ACM (26:10), 1983, pp. 785-793.

Kanter, R. M. The Change Masters. New York: Simon and Schuster, 1983.

Keil, M., and Erran, C. "Customer-developer Links in Software Development," Communications of the ACM (38:5), 1995, pp. 33-50.

Kelly, G. A. The Psychology of Personal Constructs. New York: W. W. Norton, 1955.

Landvater, D. Control of the Business Newsletter. Newbury, NH: The Oliver Wright Companies, 1985.

Langnau, L. “Glitz and Hype Signal Caution,” Material Handling Engineering (53:5), May 1998 53:5

Lawrence, M., and Low, G. "Exploring Individual User Satisfaction within User-led Development,” MIS Quarterly (2), 1993, pp. 195-208.

Leavitt, H. J. "Applied Organizational Changes in Industry: Structural, Technological, and Heuristic Approaches," in Handbook of Organizations, J. G. March (ed.). New York: Rand McNally, 1965, pp. 1144-1170.

Levin, R.; Mateyaschuk, J.; and Stein, T. "Faster ERP Rollouts," Information Week, July 13, 1998.

Lucas, H. "Management Information Systems," Management Accounting, (61:6), 1979, pp. 8, 63.

Lucas, H. Implementation, The Key to Successful Information Systems. New York: Columbia, 1981.

Lucas, H.; Walton, E.; and Ginzberg, M. "Implementing Packaged Software," MIS Quarterly, December 1988, pp. 537-549.

Lynch, R. "Implementing Packaged Application Software: Hidden Costs and Challenges," Systems, Objectives, Solutions (4), 1984, pp. 227-234.

Martin, M. "An Electronics Firm Will Save Big Money by Replacing Six People with One and Lose All the Paperwork, Using Enterprise Resource Planning Software. But Not Every Company Has Been So Lucky," Fortune (137:2), 1998, pp. 149-151.

McKie, S. "Packaged Apps for the Masses," DBMS. (10:11), October 1997, pp. 64-66, 68.

Nandhakumar, J. "Design for Success? Critical Success Factors in Executive Information Systems Development," European Journal of Information Systems (5), 1996, pp. 62-72.

Newman, M., and Robey, D. "A Social Process Model of User-Analyst Relationships," MIS Quarterly (16:2), 1992, pp. 249-266.

Piszczalski, M. "Lessons Learned from Europe's SAP Users,” Production (109:1), January 1997, pp. 54-56.

Reich, B. H., and Benbasat, I. "An Empirical Investigation of Factors influencing the Success of Customer-Oriented Strategic Systems," Information Systems Research (1:3), September 1990, 325-347.

Rivard, S., and and Huff, S. "User Developed Applications: Evaluation of Success from the DP Department Perspective," MIS Quarterly (8:1), 1984, pp. 39-50.

Robey, D. "User Attitudes and Management Information Use," Academy of Management Journal, September 1979, pp. 527-538. 
Rogers, E. M. The Diffusion of Innovations, $3^{\text {rd }}$ ed. New York: Free Press, 1983.

Stedman, C. "Business Application Rollouts Still Difficult," Computerworld (32:28, November 2, 1998a, pp. 53, 56.

Stedman, C. "ERP User Interfaces Drive Workers Nuts," Computerworld (32:44), November 2, 1998 b, pp. 1, 24.

Steen, M. "Enterprise Resource Planning Teams Learn by Doing as Well as Training," InfoWorld (20:45), November 9, 1998.

Steinbart, P. J., and Nath, R. "Problems and Issues in the Management of International Data Communications Networks: The Experiences of American Companies," MIS Quarterly (16:1), 1992, pp. 55-76.

Swanson, E. B. "Management Information Systems: Appreciation and Involvement," Management Science (21:2), 1974, pp. 178-188.

Swanson, E. B. "Information Channel Disposition and Use," Decision Sciences (18:1), 1987, pp. $131-145$

Tebbe, M. "War Stories Outnumber Successes When It Comes to Implementing SAP," (19:27), July 7, 1997, p. 120.

White, E. M.; Anderson, J.; Schroeder, R., and Tupy S. "A Study of the MRP Implementation Process," Journal of Operations Management, 1982, pp. 145-154.

Woodward, J. Industrial Organization: Theory and Parts. London: Oxford University Press, 1965.

Wrenden, N. "Model Business Processes," Information Week, September 1998, pp. 1A-8A.

\section{About the Authors}

Anne Parr is a lecturer in the School of Business Systems at Monash University. She is currently completing a Ph.D. in ERP systems implementation at Monash University. Her research interests are in tourism and medical information systems, expert systems in medicine and ERP systems implementation. She has published research papers in several international conferences. Anne is the contact author for this paper and can be reached at anne.parr@infotech.monash.edu.au.

Graeme Shanks is an associate professor in the Department of Information Systems at The University of Melbourne. He holds a Ph.D. in information systems from Monash University. His research interests are in data warehousing, data quality, requirements modeling, and organizational implementation of information technology. He has published research papers in Information Systems Journal, Journal of Strategic Information Systems, Information and Management, Requirements Engineering Journal, Australian Computer Journal, Australian Journal of Information Systems, and Data Warehousing Journal.

Peta Darke is a senior lecturer in the School of Information Management and Systems at Monash University. She holds a Ph.D. in information systems from Monash University. Her research interests are in requirements definition, data quality, data warehousing, enterprise systems, and conceptual modeling. She has published research papers in Information Systems Journal, Information and Management, Requirements Engineering Journal, Australian Computer Journal, Australian Journal of Information Systems and Data Warehousing Journal. 